\title{
Recursos fisioterapêuticos na prevenção da perda da densidade mineral óssea com lesão medular
}

\author{
Physiotherapy resources on bone mineral density loss prevention \\ in patients with spinal cord injuries
}

Danielle Rodrigues ${ }^{1}$, Guilherme Herrera ${ }^{2}$

\section{RESUMO}

Este trabalho é uma revisão bibliográfica sobre os tratamentos fisioterápicos destinados a prevenção, estabilização ou lentificação da perda da densidade mineral óssea em pacientes portadores de lesão medular. Foram encontrados poucos trabalhos que se destinaram aos tratamentos fisioterápicos para desmineralização óssea. Em relação aos tipos de tratamentos encontrados foram: estimulação elétrica funcional, estimulação elétrica funcional com bicicleta ergométrica, ortostatismo e deambulação. Estes tratamentos são bastante questionáveis não tendo um consenso na metodologia, apresentando muitas controvérsias em relação à eficácia dos tratamentos, que serão discutidos no decorrer deste trabalho.

Descritores: Lesão medular; Osteoporose, Reabilitação.

\section{INTRODUÇÃO}

No Brasil, há 130 mil indivíduos portadores de lesão medular e cada ano está incidência vem aumentando devido aos acidentes automobilísticos e principalmente à violência(15). Os indivíduos com lesão medular tem perda parcial ou total da função motora, sensitiva, autônomo, e complicações no sistema orgânico, sendo uma delas a alteração do metabolismo ósseo que conseqüentemente levará à osteoporose.

Esta perda óssea (desmineralização) é conhecida na literatura, porém sua causa não está bem esclarecida, ocorrendo no primeiro ano após a lesão medular com pico no 4-6 mês de lesão, acometendo as regiões proximais e distais dos ossos preferindo primeiro a camada trabecular e depois a camada compacta do osso.

Com a desmineralização, o risco de fratura aumenta ${ }^{(8,20)}$, podendo

\section{SUMMARY}

This work is bibliographic review about the physiotherapy treatments for the attenuation, prevention and stabilization or slowing down of the bone mineral density loss in spinal cord injured patients. There are few studies focusing the efficiency the physiotherapy treatment for bone demineralization. The kinds of treatments found were: functional electrical stimulation, functional electrical stimulation with an bycicle ergometry, orthostatic and deambulation. These treatments are much questionable, and with no consensus on the methodology, with the lot of controversies in relation to the efficacy of the treatments, which are going to be discussed in the development of this study.

Key words: Spinal cord injury; Osteoporosis; Rehabilitation.

\section{INTRODUCTION}

In Brazil, there are 130 thousand individuals bearers of spinal cord injury and every year its incidence is increasing due to the automobile accidents and mainly to the violence15. The individuals with spinal cord injury suffer the partial or total loss of the motive, sensitive, autonomous functions, and complications in the organic system, and one of them is the alteration of the bone metabolism, which, consequently, results in osteoporosis.

This bone loss (demineralization) is known in the literature, however its cause is not very clear, and it occurs during the first year after the spinal cord injury with the peak in the 4-6 month of lesion, attacking the proximal and distal areas of the bones preferring first the trabecular and then the compact layer of the bone.

With the demineralization, the fracture risk increases 8,20, occurring with as deformities, ulcerations, limitations for the rehabilitation, generating difficult handling situations, so much for sufferers as for their relatives or caretakers, besides the high economic costs due to the
Trabalho realizado Cento Universitário São Camilo

1 - Fisioterapeuta formada pelo Centro Universitário São Camilo. 2 - Especialista em Neurologia pela UNIFESP - EPM, Mestrando em Ciências da Saúde pela UNIFESP - EPM.

Endereço para correspondência: R. Constantino de Sousa 1025, apto 19. Campo Belo. São Paulo. SPCEP: 04605003

e-mail: dani.rodri@uol.com.br
Work performed São Camilo University Center

1 - Physiotherapist by the Centro Universitário São Camilo. 2 - Neurology Specialist by UNIFESP - EPM, Masters in Health Science by UNIFESP - EPM.

Adress: R. Constantino de Sousa 1025, apto 19. Campo Belo. São Paulo. SPCEP: 04605003

e-mail: dani.rodri@uol.com.br 
ocorrer deformidades, ulceras, limitações para reabilitação, gerando situações de difícil manejo, tanto para os indivíduos acometidos quanto para seus familiares ou cuidadores, além dos altos custos econômico decorrente dos cuidados e com as internações, pois o custo de fratura por osteoporose é alto, nos EUA foram gastos 13.8 bilhões de dólares com tratamento médico ${ }^{(29)}$ e na França, o total de custo foi aproximadamente 200 milhões ${ }^{(14)}$.

Tendo em vista as várias complicações que se seguem após uma fratura e o alto custo para o tratamento, é interessante prevenir a perda da densidade mineral óssea nos pacientes com lesão medular. O objetivo deste trabalho é revisar a literatura para verificar a eficácia dos tratamentos fisioterápicos no que se refere à prevenção, estabilização ou lenhificação da perda da densidade óssea.

\section{DISCUSSÃO}

A perda da densidade mineral óssea (DMO) em pacientes com lesão medular é bem conhecida, porém sua causa não está bem esclarecida. Inicialmente devemos considerar algumas hipóteses com relação à perda da densidade mineral óssea:

- Há autores ${ }^{(4)}$ que mencionam que a perda óssea ocorre por alteração do sistema nervoso simpático, diminuindo o fluxo sangüíneo em algumas áreas do osso, com isso não há trocas gasosas e nem nutrientes, ocorrendo necrose celular, ativando as células osteoclásticas, o que explica a predominância da desmineralização nas áreas altamente vascularizadas ${ }^{(4)}$.

- Acreditam que a desmineralização ocorre pela falta de força mecânica e falta de força de compressão, resultando no aumento da reabsorção óssea ${ }^{(1)}$.

- Consideram que a perda óssea ocorre não por inatividade, mas sim pela ausência da pressão longitudinal dos ossos longos ${ }^{(21)}$. Verificaram que indivíduos paraplégicos e tetraplégicos não estão aptos para sustentação de peso nos membros inferiores e desta forma não ficam expostos às forças nem à tensão muscular necessárias para estimular a formação óssea tendo disparo das atividades osteoclásti$\operatorname{cas}^{(12)}$

A desmineralização ocorre no primeiro ano após a lesão medular, com pico no quarto - sexto mês de lesão, sendo evidenciada nas primeiras semanas após a lesão. O osso trabecular é o mais susceptível à osteoporose, com perda óssea de $4 \%$ ao mês nos ossos esponjosos e $2 \%$ nos ossos corticais ${ }^{(18,28)}$ sendo que os ossos mais afetados são os que suportam mais força de compressão(1). Nos membros inferiores as regiões mais afetadas são epífise distal do fêmur (70\%) e epífise proximal da tíbia (52\%) com predominância em áreas altamente vascularizadas nos ossos longos ${ }^{(4)}$. Sendo que a perda óssea é menor no fêmur proximal, pois está protegido por alguma força residual exercida pelo tronco quando sentado na cadeira de rodas ${ }^{10}$.

A diminuição da densidade mineral óssea ocorre em ordem decrescente: tetraplégico completo, incompleto; paraplégico completo, incompleto ${ }^{(16)}$. Segundo Wilmet e cols ${ }^{(28)}$, verificaram que espasticidade não foi suficiente para manter a integridade do esqueleto, sendo igual para ambos pacientes flácidos e espásticos. Porém Demirel ${ }^{(3)} \mathrm{e}$ cols. observaram que não há diferença entre tetraplégico e paraplégi$\mathrm{co}$, com perda mais aparente nos pacientes com lesões completos e flácidos.

Foram encontrados poucos trabalhos que se destinaram a verificar a efetividade dos tratamentos fisioterápicos. Em relação ao tipo de tratamento utilizado, para combater a desmineralização óssea, encontramos: cares and with hospital admissions, because the cost of the fracture for osteoporosis is high, in the USA 13.8 billion dollars were spent with medical treatments29 and in France, the total cost was of approximately 200 million $^{14}$.

Considering the several complications that follow after the fracture and the high cost for its treatment, it is interesting to prevent the bone mineral density's loss for the spinal cord injury patients, and the objective of this study is to review the literature to check the effectiveness of the physiotherapeutic treatments concerning the prevention, stabilization or slowing down of the loss of bone density.

\section{DISCUSSION}

The loss of the bone mineral density (BMD) in spinal cord injured patients is very well known. However its cause is not very clear. Initially we should consider some hypotheses regarding the loss of the bone mineral density:

There are authors that mention that the bone loss occurs due to an alteration of the sympathetic nevous system, reducing the blood flow in some areas of the bone, with that there are no gaseous exchanges and no nutrients, resulting in cellular necrosis, activating the osteoclastic cells, what explains the predominance of demineralization in the highly vascularized areas ${ }^{(4)}$.

It is believed that demineralization occurs due to the lack of mechanical force and lack of compression force, resulting in the increase of the bone reabsorption ${ }^{(1)}$.

It is considered that the bone loss doe snot occur due to inactivity, but due to the absence of the longitudinal pressure of the long bones ${ }^{(21)}$. It was observed that paraplegic and tetraplegic individuals are not capable to sustain weight on their lower limbs and as such they are not exposed to the forces or to the necessary muscular tension to stimulate the bone formation, resulting in the triggering of the osteoclastic activities $^{(12)}$.

The demineralization occurs during the first year after the spinal cord injury, with the peak in the fourth-sixth month from the injury, and it is evidenced in the first weeks after the injury. The trabecular bone is the more susceptible to osteoporosis, with the bone loss of $4 \% /$ month in the spongy bones and $2 \%$ in the cortical bones ${ }^{(18,28)}$ and the most affected bones are the ones that support more compression force ${ }^{(1)}$. In the lower limbs the most affected areas are the distal epiphyses of the femur (70\%) and the proximal epiphysis of the shinbone (52\%) with predominance in highly vascularized areas in the long bones ${ }^{(4)}$. The bone loss is smaller in the proximal femur, because it is protected by some residual force exercised by the trunk while seated on the wheelchair ${ }^{(10)}$.

The decrease of the bone mineral density occurs in decreasing order: totally tetraplegic, not totally tetraplegic, totally paraplegic, not totally paraplegic ${ }^{16}$. According to Wilmet and co/s $\mathrm{s}^{(28)}$, it was observed that the spasticity was not enough to maintain the integrity of the skeleton, being the same for both, flaccid and spastic patients. However Demirel and cols. ${ }^{(3)}$ observed that there is no difference between tetraplegic and paraplegic, with more apparent loss in the patients with complete and flaccid injuries.

Few studies were found focused on the effectiveness of the physiotherapy treatments. In relation to the type of treatment used to fight bone demineralization we found:

- Functional electrical stimulation/ bycicle ergometry ${ }^{(1,7,13,24)}$; 
- Estimulação elétrica funcional / bicicleta ergométrica ${ }^{(1,7,13,24)}$;

- Estimulação elétrica funcional (EEF) ${ }^{(2,7)}$;

- Ortostatismo ${ }^{(3,6,11,26)}$;

- Deambulação(3,9,19,22);

Tendo em vista os diversos tipos de tratamento disponíveis procuramos verificar a efetividade de cada um:

- Estimulação elétrica funcional / bicicleta ergométrica: não foi efetivo para reverter, lentificar ou estabilizar a desmineralização óssea em pacientes com lesão medular ${ }^{(13,24,7,1)}$;

- Estimulação elétrica funcional: não é eficaz para combater a perda da $\mathrm{DMO}^{(7)}$, entretanto, há autores que verificaram que a EEF foi responsável pelo aumento da $\mathrm{DMO}^{(2)}$;

- Ortostatismo: não foi efetivo para reverter, lentificar ou estabilizar a desmineralização em pacientes com lesão medular ${ }^{(11,26)}$, já outros trabalhos verificaram que pode prevenir ou retardar a perda óssea, e que os resultados foram melhores nos grupos que usaram órtese ${ }^{(3,6)}$;

- Deambulação: previne ou retarda a perda da densidade mineral óssea ${ }^{(3,9,19)}$, porém Shropshire e cols. ${ }^{(22)}$ não concordaram, pois não verificaram melhora na DMO.

Como podemos observar não existe consenso no que diz respeito à eficácia dos diversos tipos de abordagem com objetivo de prevenir, lentificar ou estabilizar a diminuição da DMO, e observamos que há muitas variáveis do tipo amostra, sexo, idade, tempo de lesão e outros que podem interferir nos resultados.

Quanto ao tamanho da amostra, a maioria dos autores ${ }^{(1-29)}$ utilizou quantidade pequena de pacientes o que pode ter interferido nos resultados obtidos. Ogilvie e cols. ${ }^{(19)}$ citaram que o número de pacientes estudados no seu trabalho foi pequeno, tendo então um desprezo para os resultados.

Outro fator importante que observamos nesta revisão consiste na heterogeneidade das amostras no que se refere à idade e sexo.

Quanto à idade dos pacientes, somente Leeds e cols. ${ }^{(13)}$ tiveram grupo de pacientes com idade mais homogênea, limitando-se a estudarem adultos. Os outros trabalhos tiveram variações muito grandes de idade, utilizando pacientes jovens, adultos jovens e idosos e isto pode interferir nos resultados, pois o pico de massa óssea mantém-se até aos 40 anos em indivíduos normais, a partir desta idade começa ter diminuição da densidade mineral óssea e esta perda pode ser mais rápida quando associado à imobilização(21, 23).

Em relação ao sexo dos pacientes, apenas 4 autores se preocuparam em selecionar uma amostra homogênia ${ }^{(1,3,11)}$, porém, os outros autores, trabalharam com ambos sexos. Todavia sabe-se que as muIheres têm uma perda óssea maior do que os homens, sendo acentuada na pós- menopausa ${ }^{(23)}$. Á vista disto, mulheres com lesão medular, dependendo da idade tem maior propensão à perda óssea do que os homens podendo influenciar nos resultados dos trabalhos.

Em vista da influência, que a idade e o sexo pode exercer sobre a $\mathrm{DMO}$, podemos inferir que a grande variação dessas duas categorias pode interferir nos resultados dos trabalhos apresentados.

Quando verificamos se os participantes dos trabalhos realizavam tratamento fisioterápico, observamos que apenas um trabalho citou que os pacientes realizavam fisioterapia, contudo não especificaram o
- Functional electrical stimulation (EEF)(2,7);

- Orthostatism ${ }^{(3,6,11,26)}$;

- Deambulation ${ }^{(3,9,19,22)}$,

Considering the several types of treatments available, we checked the effectiveness of each one:

- Functional electrical stimulation / bycicle ergometry: not effective to revert, slow down or stabilize the bone demineralization in patients with spinal cord injury $(1,7,13,24)$;

- Functional electrical stimulation: not effective other hand(7), there are authors that observed that the EEF was the responsible for the increase in the $B M D^{(2)}$;

- Orthostatism: not effective to revert, slow down or stabilize the demineralization in spinal cord injured patients ${ }^{(11,26)}$. Other studies observed that it can prevent or delay the bone loss, and that the results were better for the groups that used osthesis ${ }^{(3,6) ;}$

- Deambulation: prevents or delays the loss of bone mineral density ${ }^{(3,9,19)}$, but Shropshire and cols. ${ }^{(22)}$ of the not agree with this because they could not observe an improvement of the BMD.

It is possible to observe that there is no consensus in the subject concerning the effectiveness of the different focus to prevent, slow down or stabilize the decrease of BMD, and we observe that there are many variables such as sample, gender, age, and time of injury and others that can interfere with the results.

The size of the sample that most used was the small quantity of patients, which may have interfered with the obtained results. Ogilvie and cols. ${ }^{(19)}$ mentioned that the number of patients observed in their study was small, and so the results were disregarded.

Another important factor that we observed in during this review was the heterogeneity of the samples for the items age and gender.

Concerning the age of the patients, only Leeds and cols. ${ }^{(13)}$ has the group of patients with the more homogenous age, limiting themselves to study adults. The other studies had very wide age variations, using young, young adults and elderly patients. This may interfere with the results, because the peak of bone mass is maintained up to the 40 years of age in normal individuals, and from that age on the decrease of bone mineral density starts, and this loss can be quicker if associated to imobilization $^{(21,23)}$

Concerning the gender of the patients, only four of the authors had the preoccupation to select the homogenous sample ${ }^{(1,3,11)}$, but the other authors dealt with both genders. However, it is widely known that women present the larger bone loss than men, which is accentuated after the menopause ${ }^{(23)}$. In view of this scenario, women with spinal cord injury, depending on their age, show more tendencies to bone loss than men, and this can influence the results of the studies.

In view of the influence that age and gender may exert on $B M D$, we can infer that the large variation of these two categories can interfere with the results of the studies presented.

When we checked if the participants of the studies did undergo physiotherapeutic treatments, we observed that only one study mentioned that the patients did undergo physiotherapy. However it did not specity the type of exercise, the frequency of the therapy and the duration of the treatment ${ }^{(24)}$.

Another point we believe is of critical importance in the reduction of $B M D$ loss is the fact that the patients trained the gait or remained in orthostatism. We analyzed the literature and observed that only one 
tipo de exercício, freqüência da terapia e duração do tratamento(24).

Outro fator que acreditamos ter importância crítica na redução da perda da DMO é o fato dos pacientes treinarem marcha ou permaneceram em ortostatismo. Analisamos a literatura e verificamos que somente um grupo de autores, comentou que nenhuns dos seus pacientes eram deambuladores e que nunca ficaram em ortostatismo ${ }^{(19)}$.

Com relação aos critérios de exclusão, foram excluídos:

- Mulheres pós - menopausa, jovens menores de 20 anos e pacientes com uso de bisfosfonato(6);

- Pacientes com lesões do motoneurônio inferior ${ }^{(7,22)}$;

- Doenças renais, do fígado, doenças cardiovasculares, fraturas e uso de medicamentos que podiam interferir no metabolismo $(2,7,9,11,22)$

Quando verificamos o tipo de lesão medular utilizada nos trabalhos encontramos uma heterogeneidade em relação ao tipo da lesão:

- Lesões traumáticas e não traumáticas ${ }^{(11)}$

- Lesões traumáticas ${ }^{(2,13,19)}$

- Sete trabalhos não mencionaram se os pacientes eram portadores de lesão medular traumática ou não traumática.

Outro fator que acreditamos ter importância crítica na redução da DMO é a gravidade da lesão medular. Verificamos que os autores não se preocuparam com a homogeneidade da gravidade da lesão e nem com a escala de deficiências da ASIA, principalmente nas lesões medulares incompleta. Somente quatro trabalhos se preocuparam em igualar os pacientes de acordo com a gravidade da lesão, igualandoos em lesões completas ${ }^{(1,6,13,22)}$ e quatro trabalhos utilizaram pacientes portadores de lesão medular incompleto e completo ${ }^{(2,3,7,24)}$.

Segundo Demirel e cols. ${ }^{(5)}$ os indivíduos com lesões medulares completas têm uma perda mais aparente comparado com os indivíduos com lesões medulares incompletas.

Quanto ao nível da lesão medular, observamos que somente Ledds e cols. ${ }^{(13)}$ se preocuparam em selecionarem pacientes com níveis de lesão mais próximos. Os outros autores utilizaram pacientes tanto com lesões medulares altas como lesões medulares baixa, isto pode interferir nos resultados dos trabalhos apresentados.

Com relação ao tônus do paciente portadores de lesão medular: autores declaram que os indivíduos espásticos têm menor perda de DMO comparado com os pacientes flácidos ${ }^{5}$, em contra partida Wilmet e cols. ${ }^{(28)}$ mencionaram que a espasticidade e manutenção da massa muscular não previnem a perda da DMO comparado com os indivíduos flácidos. Segundo Goemaere e cols. ${ }^{(6)}$, o grau de espasticidade e o nível da lesão não afetam a DMO.

Relacionando o tempo de lesão, somente três trabalhos selecionaram pacientes com lesões precoce, com menos de 6 meses de lesões ${ }^{(3,9,22)}$. Houve trabalhos que utilizaram pacientes com tempo de lesão acima de um ano, tendo uma variação muito grande, podendo interferir nos resultados dos trabalhos apresentados. Sabe-se que a perda da mineralização óssea ocorre nos primeiros seis meses de lesão com pico no quarto mês, estabilizando durante 12-16 meses após lesão medular ${ }^{(27)}$. À vista disto demonstra a importância da intervenção precoce. group of authors commented that none of its patients were deambulators, and those ever remained in orthostatism ${ }^{(19)}$.

Concerning the exclusion criteria, the following individuals were not included:

- Post-menopausal women, youngsters with less than 20 years of age and patients taking bisphosphanate ${ }^{(6)}$;

- Patients with injuries to the inferior motoneuron (7,22);

- Hepatic diseases of the liver, cardiovascular diseased. Fractures and the use of drugs that can interfere with the metabolism ${ }^{(2,7,9,11,22)}$;

When the type of spinal cord injury used in the studies were checked, we observed heterogeneity in relation to the type of injury:

- Traumatic and non-traumatic inuries ${ }^{(11)}$

- Traumatic injuries ${ }^{(2,13,19)}$

- Seven studies did not mention that the patients were sufferers of traumatic or non-traumatic spinal cord injury.

Another factor we think is of critical relevance for the decrease of $B M D$ is the seriousness of the spinal cord injury. It was observed that the authors did not worry with the homogeneities of the seriousness of the injury, or with the deficiency scale of ASIA, mainly the incomplete spinal cord injuries. Four studies only leveled the patients according to the seriousness of the injury, leveling them as total injuries ${ }^{(1,6,13,22)}$ and four studies used patients with non-total and total spinal cord inju$r y^{(2,3,7,24)}$.

According to Demire/ and cols. (5) the individuals with total spinal cord injuries present a more apparent loss in comparison to the individuals with non-total spinal cord injuries.

Concerning the level of the spinal cord injury, it was observed that only Leeds and cols. ${ }^{(13)}$ selected the patients with closer levels of injury. The other authors used patients with high spinal cord injuries and low spinal cord injuries, this can interfere with the results of the studies presented.

Concerning the tonus of the patient bearer of the spinal cord injury, the authors stated that the spastic individuals have a lower loss of BMD as compared to the flaccid patients ${ }^{(5)}$. On the other hand, Wilmet and cols. ${ }^{(28)}$ mentioned that the spasticity and maintenance of the muscular mass do not prevent the loss of the BMD as compared to the flaccid individuals. According to Goemaere and cols. ${ }^{(6)}$, the level of spasticity and the level of the injury do not affect the BMD.

Concerning the time from the injury, only three studies selected patients with early injuries, with less than 6 months of the injuries ${ }^{(3,9,22)}$. There were studies that used patients with a time from the injury above one year, with a very wide variation, with a possible interference in the results of the studies presented. The loss of the bone mineralization is known to occur in the first six months from the injury with a peak on the fourth month, and remaining stabilized during 12-16 months after the spinal cord injury ${ }^{(27)}$. This determines the importance of the early intervention.

Concerning the measuring techniques used in the studies, we found:

- $D E X A^{(1,2,6,11,13,22,24,25,26)}$,

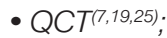

- XRAYS ${ }^{(17,25)}$.

There was a wide variation concerning the site of the measurement 
Em relação, as técnicas de mensuração utilizadas encontramos:

- $\operatorname{DEXA}^{(1,2,6,11,13,22,24,25,26)}$,

- $\mathrm{QCT}^{(7,19,25)}$;

- $\mathrm{RAIO}-\mathrm{X}^{(17,25)}$.

Houve uma grande variação, a respeito ao local da mensuração da densidade mineral óssea:

- Coluna lombar ${ }^{(1,11,19,24,26)}$;

- Colo do fêmur ${ }^{(1,6,11,13,19,22,24,26)}$

- Trocanter ${ }^{(1,6,13,22,24)}$;

- Diáfise do fêmur ${ }^{(2,6)}$;

- Distal do fêmur, diáfise e proximal da tíbia $(2,7)$.

Segundo Dauty e cols. ${ }^{(14)}$, a área mais afetada com perda da DMO é a metáfise e epífise do fêmur distal e proximal da tíbia.

Kiralti e cols. ${ }^{(10)}$ mencionaram que a desmineralização óssea da coluna lombar e do fêmur proximal são menores, devido à força residual exercida pelo tronco quando sentado na cadeira de rodas.

Não houve uniformidade nos trabalhos em que se refere à duração, freqüência e o tipo de trabalho utilizado.

Verificamos, que somente Goemaere e cols. ${ }^{(6)}$, compararam a efetividade de 3 invenções de ortostatismo para DMO em pacientes com lesão medular, utilizando a órtese, standing frame e a cadeira de rodas que fica em ortostatismo. Dos 3 equipamento, a órtese foi a que teve maior descarga, devido ao peso axial que ela proporciona, sendo, a mais eficaz para diminuir a perda da DMO.

\section{CONCLUSÃO}

De acordo com a revisão bibliográfica a perda de densidade mineral óssea nas áreas paralisadas é bem conhecida, sendo uma das principais complicações dos pacientes portadores de lesão medular, porém o que leva esta perda não está claramente estabelecido.

Em relação ao objetivo do trabalho concluímos que não podemos mencionar quais os exercícios foram eficazes ou não, pois não houve resultados consistentes no que se refere à prevenção, lentificação da perda da DMO. Observamos que a maioria dos trabalhos estudados não estabeleceram uma metodologia adequada, apresentando grandes falhas no que se refere principalmente aos critérios de inclusão.

Acreditamos que novos trabalhos devem ser realizados contendo critérios de inclusão bem definidos como, por exemplo: o tempo da lesão, tipo da lesão (completa ou incompleta), nível da lesão (cervical, torácica alta, torácica baixa, lombar), idade, sexo, estar em tratamento fisioterápico, tipo de tratamento, portadores de órteses que possibilitam o ortostatismo ou treino de marcha.

\section{AGRADECIMENTOS}

Ao Guilherme Herrera, professor e orientador deste trabalho. ̀ professora e coordenadora Marta Damasceno. Ao Centro Universitário São Camilo e à Fundação Selma. of the bone mineral density:

- Lumbar spine ${ }^{(1,11,19,24,26)}$;

- Femur neck ${ }^{(1,6,11,13,19,22,24,26)}$

- Trocanter $r^{(1,6,13,22,24) \text {; }}$

- Diaphysis of the femur ${ }^{(2,6)}$;

- Distal of the femur, diaphysis and proximal of the tíbia(2,7).

According to Dauty and cols. (4), the most affected are with loss of the BMD is the metaphysis and the epiphysis of the femur distal and proximal of the tibia.

Kiratli and cols. ${ }^{(10)}$ mention that the bone demineralization of the lumbar spine and of the proximal femur are smaller due to the residual force excerpted by the trunk when seating on a wheelchair.

There was no uniformity in the studies in what refers to the duration, frequency and the type of study used.

It was observed that only Goemare and cols. ${ }^{(6)}$, compared the effectiveness of the 3 orthostatism inventions for BMD in spinal cord injured patients, using the orthesis, standing frame and the wheelchair that remains in orthostatism. The orthesis was the equipment with a better discharge, among the three equipments, due to the axial weight it supplies, and thus being the more efficient in the reduction of the loss of the BMD.

\section{CONCLUSION}

According to the bibliographical review, the loss of bone mineral density in the paralyzed areas is well known, and is one of the major complications for the spinal cord injured patients. However, which is the factor that results in this loss is not clearly established.

Concerning the objective of the study, it was concluded that we cannot mention which are the exercises that were effective, or not, because there were no consistent results concerning prevention or slowing down of the loss of the BMD. It was observed that the majority of the studies reviewed did not determine an adequate methodology, presenting major flaws referring mainly to the inclusion criteria.

We believe that new studies should be performed, with well defined inclusion criteria, such as, for example: the time from the injury, type of the injury (total or non-total), level of the injury (cervical, high thoracic, low thoracic, lumbar), age, gender, under physiotherapeutic treatment, type of treatment, orthesis bearers that enable orthostatism or gait training.

\section{ACKNOWLEDGEMENTS}

Guilherme Herrera, professor and advisor for this study. Marta Damasceno, professor and coordinator. Centro Universitário São Camilo and to the Selma Foundation. 


\section{REFERÊNCIAS BIBLIOGRÁFICAS}

1. BEDELL, Kimberly; SCREMIN, Erika; PERELL, Karen e cols. Effects of functional electrical stimulation - induced lower extremity cycling on bone density of spinal cord - injured patients. Am. Journal of physical medicine and rehabilitation. V. 75, n. 1, p. 29-34, 1996

2. BÉLANGER, Marc; STEIN, Richard B.; WHEELER, Garry D. e cols. Electrical stimulation: Can it increase muscle strength and reverse osteopenia in spinal cord injured individuals? Arch. Phys. Med. Rehabil. V. 81, p. 1090-1098, 2000.

3. BRUIN, Eling D.; RINDOVA, Frey, e cols. Changes of tibia bone Properties after spinal cord injury: Effects of early intervention. Arch. Phys. Med. Rehabil. V. 80, n 2, p. $214-20.1999$.

4. DAUTY, M; VERBE, B. Perrouin; MAUGARS, Y e cols. Supralesional and sublesional bone mineral density in spinal cord-injured patients. Bone. V.27, n. 2, p. 3059,2000

5. DEMIREL, Gülçin; YILMAZ, Hurriyet, PARKER, Nurdan e cols. Osteoporosis after spinal cord injury. Spinal cord. V. 36, n.12, p. 822-825. 1998.

6. GOEMAERE, S.; LAERE, Van; NEVE, P.; KAUFMAN, J. M. e cols. Bone mineral status in paraplegic patients who do or do not perform standing. Osteoporosis international. V. 4, p. 138-43. 1994

7. HANGARTNER, Thomas; RODGERS, Marry; GLASER, Roger e cols. Tibial bone density loss in spinal cord injured patients: Effects of FES exercise. Journal of rehabil. research and development.V31, n. 1, p. 50-61, 1994

8. HARTKOPP, Andreas; MURPHY, René J.; MOHR, Thomas e cols. Bone fracture during electrical stimulation of the quadriceps in a spinal cord injured subject. Arch. Phys. Med. Rehabil. V. 79, p. 1133-6, 1998.

9. KAPLAN, Paul; ANDHAVADI, Balaraju: RICHARDS, Lois e cols. Calcium balance in paraplegic patients: influence of injury duration and ambulation. Arch. Phys. Med. Rehabil. V. 59, p. 447-50.1978

10. KIRATLI, B. J.; SMITH, A.E.; NAUENBERG, T. e cols. Bone mineral and geometric changes through the femur with immobilization due to spinal cord injury. Journal Rehabil. Res. Development. v. 37, n. 2, 2000.

11. KUNKEL, Charles; SCREMIN, Erika; EISENBERG, Brian e cols. Effect of "standing" on spasticity, contracture, and osteoporosis in paralyzed males. Arch. Phys. Med. Rehabil. V. 74, p. 73-78. 1993.

12. LEE, Thay Q; SHAPIRO, Todd; BELL, David. Biomechanical properties of human tibias in long - term spinal cord injury. Journal Rehabil. Res, Dev. V. 34, n.3, p. 295302, 1997.

13. LEEDS, Eileen; KLOSE, JOHN; GANZ, WILLIAM e cols. Bone mineral density after bicycle ergometry training. Arch. Phys. Med. Rehabil. V. 71, n. 3, p. 207-9, 1990.

14. LEVY, P.; LEVY, E.; AUDRAN, M. e cols. The cost of osteoporosis in men: The french situation. Bone. V. 30, n. 4, p. 631-636,2002.
15. LIANZA, Sérgio. Órtese de propulsão recíproca modelo argo método de avaliação, tratamento e análise de resultados na reeducação da locomoção em pacientes com lesão medular. Tese apresentada ao curso de pós graduação da faculdade de medicina da Santa Casa de São Paulo. São Paulo, 1997.

16. LIU, C.C.; THEODOROU, D. J.; ANDRE, M. P. e cols. Quantitative computed tomography in the evaluation of spinal osteoporosis following spinal cord injury. Osteoporosis international. V. 11, n. 10, p. 889-96, 2000

17. LIYANG, Dai; CHUNLIN, Hou. Double cortical line in the acetabular roof of paraplegic patients. Chinese medical journal. V. 108, n. 1, p. 63-5, 1995

18. NAFTCHI, Eric; VIAU, Anna; SELL, Heiner e cols. Mineral metabolism in spinal cord injury. Arch. Phys. Med. Rehabil. V. 61, p.139-42, 1980.

19. OGILVIE, C.; BOWKER, P.; ROWLEY, D. I. e cols. The physiological benefits of paraplegic orthotically aided walking. Paraplegia. V. 31, n. 2, p. 111-115, 1993.

20. RAGNARSSON, Kristian, SELL, Heiner. Lower extremity fractures after spinal cord injury: a retrospective study. Arch. Phys. Med. Rehabil. V. 62, p. 418-423. 1981.

21. RUTHERFORD, Olga M. The role of exercise in prevention of osteoporosis. Physiotherapy. V. 76, n. 9, p.522-526, 1990.

22. SHROPSHIRE, Belinda; BROTON, James; KLOSE John e cols, Evaluation of a training program for persons with $\mathrm{SCl}$ paraplegia using the Parastep 1 ambulation system: Part 3. Lack of effect on bone mineral density. Arch. Phys. Med. Rehabil. V. 78, n.8, p. $799-803,1997$

23. SKARE, Thelma Larocca. Reumatologia: princípios e prática. Rio de Janeiro: Guanabara Koogan. 1999.

24. SLOAN k. E, BREMNER, L. A; BYRNE, J. DAY, R. E. e cols. Musculoskeletal effects of an electrical stimulation induced cycling programme in the spinal injured. $\mathrm{Pa}$ raplegia. V.32, n. 6, p. 407-415. 1994.

25. SZEJNFELD, Vera Lúcia. Osteoporose: diagnóstico e tratamento. São Paulo: Sarvier, 2000.

26. THOUMIE, P; BEILOT, J.; CLAIRE, G. Le e cols. Restoration of functional gait in paraplegic patients with the RGO-II hybrid orthosis. A multicenter controlled study. II: Physiological evaluation. Paraplegia. V. 33, p. 654-659. 1995.

27. UEBELHART, D.; DOMENECH, Demiaux; CHANTRAINE, A. e cols. Bone metabolism in spinal cord injured individuals and in others who have prolonged immobilization. A review. Paraplegia. V. 33, n. 11, p. 669-673, 1995

28. WILMET, E.; ISMAIL, A.; HEILOPORN, A. e cols. Longitudinal study of the bone mineral content and of soft tissue composition after spinal cord section. Paraplegia. V. 33, n. 11, p. 674-677. 1995

29. ZERBINI, Cristiano A. F. Osteoporose - revisão. Revista Bras. Clín. Terap. V.24, n. 1 , p. 22-26. 1998 